\title{
Toscana Virus: Ten Years of Diagnostics in Portugal
}

\section{Vírus Toscana: Dez Anos de Diagnóstico em Portugal}

\author{
Fátima AMARO $\bigotimes^{1}$, Líbia ZÉ-ZÉ1, Maria Teresa LUZ1, Maria João ALVES ${ }^{1}$ \\ Acta Med Port 2021 Oct;34(10):677-681 • https://doi.org/10.20344/amp.13308
}

\section{ABSTRACT}

Introduction: Toscana virus (TOSV) is an emerging sandfly-borne virus within the Phlebovirus genus. Although most infections caused by this virus present as asymptomatic or with minimal symptomatology, TOSV may emerge as a febrile disease or sporadic cases of neurological disease such as meningitis or meningoencephalitis. This pathogen is distributed throughout the Mediterranean basin, along with the spatial distribution of its recognized sandfly vector, Phlebotomus perniciosus. Portugal, after Italy, was the second country considered endemic for this virus, with the first case of acquired infection published in 1985. Although little is known about the circulation of this virus in Portugal, the laboratory diagnosis of TOSV is available at the Centre for Vectors and Infectious Diseases Research of the National Institute of Health Dr. Ricardo Jorge (CEVDI/INSA), since 2007. The aim of this study is to report the results of the diagnosis of TOSV at the CEVDI/INSA, between 2009 and 2018.

Material and Methods: The diagnosis of TOSV in the CEVDI/INSA is included in the arboviruses and vector-borne neurotropic viruses panels or can be performed, when specified, for TOSV only. Direct detection is made in cerebrospinal fluid samples and is available for TOSV by specific real-time reverse transcription polymerase chain reaction followed by conventional real-time reverse transcription polymerase chain reaction for sequencing purposes, if positive. For indirect diagnosis, performed in serum samples, an in-house immunofluorescence assay for the detection of $\mathrm{IgM}$ and $\mathrm{IgG}$ antibodies against TOSV is used. A commercial immunofluorescence assay consisting in a mosaic of four phleboviruses is also available, in which, in addition to TOSV, antibody detection for sandfly fever Naples virus, sandfly fever Sicilian virus and sandfly fever Cyprus virus can be done. All diagnostic tests requested by clinicians to the CEVDI/ INSA for arboviruses, neurotropic viruses and/or TOSV between January 2009 and December 2018, were included in this study.

Results: During the study period, the CEVDI/INSA received samples from 608 patients with diagnostic requests for TOSV. Five acute TOSV infections and one acute sandfly fever Sicilian virus infection were confirmed in serum samples. Three other patients had serological evidence of previous contact with the virus. Two of the six patients with acute infection developed febrile syndrome, and the other four presented with neurological disease: meningitis $(n=2)$, meningoencephalitis $(n=1)$ and severe depression of consciousness $(n=$ 1). These infections were most likely acquired in the districts of Faro (3), Lisbon (2) and Setúbal (1).

Discussion: In Portugal, the number of laboratory diagnostic requests for TOSV is low when compared to the number of requests for other less prevalent vector-borne viruses. The Faro district presented the highest number of TOSV-specific diagnostic requests which seems to indicate a higher level of recognition by clinicians in that region. Febrile syndrome and neurological disease were the clinical manifestations that were present in acute cases. In this study, in addition to the Faro district, recent infections were also detected in the districts of Lisbon and Setúbal. It is probable that TOSV may be distributed throughout the mainland territory since its main vector is present from north to south. In 2017, the sandfly fever Sicilian virus was associated for the first time with human disease in our country, thus alerting to the circulation of this phlebovirus.

Conclusion: Even though the number of identified cases in Portugal is low, TOSV circulates and causes disease in our country. The diagnosis of this and other phleboviruses should not be neglected in the differential diagnosis of febrile syndrome and viral meningitis and meningoencephalitis, especially during the warmer months, when the vector's activity is higher.

Keywords: Phlebovirus; Portugal

\section{RESUMO}

Introdução: O vírus Toscana (TOSV) é um vírus emergente, transmitido por flebótomos, que pertence ao género Phlebovirus. Apesar de a maioria das infeções causadas por este vírus serem assintomáticas ou apresentarem uma sintomatologia ligeira, o TOSV pode causar síndrome febril ou casos esporádicos de doença neurológica tais como meningite ou meningoencefalite. Este agente patogénico encontra-se distribuído por toda a bacia do Mediterrâneo, de acordo com as áreas de distribuição do seu vetor reconhecido, Phlebotomus perniciosus. Depois de Itália, Portugal foi o segundo país considerado endémico para este vírus após a publicação, em 1985, do primeiro caso de infeção adquirida no nosso território. Apesar do pouco conhecimento acerca da circulação deste vírus, no nosso país, o diagnóstico laboratorial de TOSV está disponível em Portugal, desde 2007, no Centro de Estudos de Vetores e Doenças Infeciosas do Instituto Nacional de Saúde Dr. Ricardo Jorge (CEVDI/INSA). O objetivo deste trabalho é dar a conhecer os resultados do diagnóstico de TOSV em Portugal, de 2009 a 2018, no CEVDI/INSA.

Material e Métodos: O diagnóstico de TOSV no CEVDI/INSA está inserido nos painéis 'arbovírus' e 'vírus neurotrópicos transmitidos por vetores' ou pode ser realizado, quando especificado, só para TOSV. O diagnóstico direto é realizado em amostras de líquido cefalorraquidiano e encontra-se disponível no CEVDI/INSA por RT-PCR em tempo real, específico para TOSV, seguido de RT-PCR convencional, no caso de a amostra ser positiva na primeira técnica, para confirmação por sequenciação. Para o diagnóstico indireto, realizado em amostras de soro, é utilizado uma técnica de imunofluorescência in-house, para a deteção de anticorpos IgM e IgG anti-TOSV. Também está disponível uma imunofluorescência comercial, com um mosaico de quatro flebovírus, onde para além do TOSV, são testados anticorpos contra três vírus da febre por flebótomos, nomeadamente Nápoles, Sicília e Chipre. Neste trabalho foram considerados os pedidos de diagnóstico ao CEVDI/INSA para arbovírus, vírus neurotrópicos e/ou TOSV, de janeiro de 2009 a

1. Centro de Estudos de Vectores e Doenças Infecciosas Dr. Francisco Cambournac. Instituto Nacional de Saúde Dr. Ricardo Jorge. Águas de Moura. Portugal.

$\triangle$ Autor correspondente: Fátima Amaro. fatima.amaro@insa.min-saude.pt

Recebido: 20 dezembro de 2019 - Aceite: 18 de novembro de 2020 - First published: 28 de maio de 2021 - Online issue published: 01 de outubro de 2021 Copyright @ Ordem dos Médicos 2021 
dezembro de 2018.

Resultados: No período em estudo, foram enviadas ao CEVDI/INSA, amostras de 608 indivíduos com pedido de diagnóstico de TOSV. Foram confirmadas cinco infeções agudas por TOSV e uma infeção aguda por vírus Sicília em amostras de soro. Três outros doentes apresentaram prova serológica de contacto prévio com o TOSV. Dois dos doentes com infeção aguda apresentaram síndrome febril, mas quatro evidenciaram quadros neurológicos: meningite $(n=2)$, meningoencefalite $(n=1)$ e alterações graves do estado de consciência $(n=1)$. Estas infeções foram, muito provavelmente, adquiridas nos distritos de Faro (3), Lisboa (2) e Setúbal (1).

Discussão: Em Portugal, o número de pedidos de diagnóstico laboratorial para TOSV é baixo quando comparado com o número de pedidos para outros vírus transmitidos por vetores. O distrito de Faro foi o que apresentou o número mais alto de pedidos de diagnóstico específicos para TOSV, o que parece demonstrar que existe um maior reconhecimento pelos clínicos daquela região. Síndrome febril e doença neurológica foram as manifestações clínicas nos casos agudos. Neste estudo, além do distrito de Faro, foram também detetadas infeções recentes nos distritos de Lisboa e Setúbal. É provável que o TOSV se encontre distribuído por todo o território continental, uma vez que o seu principal vetor está presente de norte a sul. Em 2017, o vírus Sicília foi associado, pela primeira vez, a doença humana no nosso país, alertando para a circulação deste flebovírus.

Conclusão: Apesar do número de casos identificados em Portugal ser baixo, o TOSV circula e causa doença no nosso país. Este e outros flebovírus não deveriam ser negligenciados no diagnóstico diferencial de síndrome febril e de meningites e meningoencefalites virais, em especial nos meses mais quentes, quando é maior a atividade dos seus vetores.

Palavras-chave: Phlebovirus; Portugal

\section{INTRODUCTION}

Phleboviruses (genus Phlebovirus, family Phenuiviridae) are arboviruses which can be transmitted by mosquitoes, ixodids or sandflies. The taxonomy of phleboviruses is quite complex. However, it is accepted that there are two species [sandfly fever Naples virus (SFNV) and Salehabad virus (SALV)], and two tentative species [sandfly fever Sicilian virus (SFSV) and Corfu virus (CFUV)] transmitted by sandflies (Diptera, Psychodidae) recognized in the Old World.

Within each species there are related viruses, some of which are well-known to be pathogenic. To date, Adria is the only virus in the SALV group that has been recognized as pathogenic to humans. It was primarily isolated from sandflies collected in Albania and whose RNA was recovered from a child with febrile syndrome in Greece..$^{1,2}$ The SFNV and SFSV are pathogens of historical importance. They were isolated for the first time from samples collected from sick soldiers in World War II, causing high morbidity among troops due to the so-called three-day fever, also known as sandfly fever or pappataci fever. ${ }^{3}$ More recently, the Cyprus virus, which belongs to the SFSV species, was isolated from a blood sample during a major outbreak of febrile syndrome, in 2002, among the Greek armed forces in Cyprus. ${ }^{4}$ Sandfly fever is clinically characterized by an incubation period ranging from three to six days, followed by high fever $\left(39^{\circ} \mathrm{C}-40^{\circ} \mathrm{C}\right)$, which persists from six to 74 hours. The most common symptoms include headache, anorexia, myalgia, photophobia, and retroorbital pain. Although persistent weakness or depression have been reported for one or more weeks after the acute phase of the disease, most patients recover within one to two weeks. ${ }^{5}$

Toscana virus (TOSV), (within the SFNV species) was isolated in 1971 in the region of Tuscany, Italy, in specimens of Phlebotomus perniciosus and P. perfiliewi sandflies (Diptera, Psychodidae). Twelve years later, in 1983, it was isolated from a patient with meningitis admitted to a hospital in the same region, ${ }^{6}$ and in the same year in Sweden, from another patient presenting with encephalitis who had acquired the infection in the Algarve. ${ }^{7}$ As a result, Portugal was considered an endemic country for this phlebovirus.

TOSV is recognized as a major pathogen not only because it may be responsible for febrile syndromes like SFNV and SFSV, but mainly for its neurotropism and ability to cause central nervous system disease. The incubation period can range from three to seven days, with a maximum of two weeks, and viremia lasting only two or three days. ${ }^{8}$ The most common clinical manifestations due to TOSV infections are fever, headache, nausea and vomiting, fatigue, photophobia, muscle weakness, febrile episodes, rash and stiff neck. It is currently the most important sandfly-borne virus in public health and is recognized as one of the three major causes of aseptic meningitis in countries around the Mediterranean Basin. It has a higher incidence in summer months, in parallel with the life cycle of its vector. ${ }^{9}$ However, it remains a poorly known pathogen in Portugal. Despite the benign course of most infections, fatal encephalitis, as well as some severe and permanent neurological sequelae in affected patients, have been reported. ${ }^{10}$ Among the atypical clinical manifestations are cases of Guillain-Barré syndrome, ${ }^{11}$ hydrocephalus, ${ }^{12,13}$ hearing loss, ${ }^{14}$ speech problems, ${ }^{15}$ paresias, ${ }^{15}$ myositis and fasciitis. ${ }^{16}$ Testicular manifestations are also documented..$^{12,17}$

Neurological symptomatology resulting from TOSV infections is clinically indistinguishable from other viral infections. Hence, laboratory diagnosis, based on direct or indirect methods, is the only way to identify infections caused by this pathogen. The laboratory diagnosis of phleboviruses in Portugal has been carried out at the national reference laboratory for the diagnosis of arboviruses, Centre for Vectors and Infectious Diseases Research from the National Institute of Health Dr. Ricardo Jorge (CEVDI/INSA) since 2007.

The aim of this study is to describe an updated case series of TOSV infection in Portugal and highlight the importance of its diagnosis, as well as that of other phleboviruses.

\section{MATERIAL AND METHODS}

Currently, direct detection of TOSV at CEVDI/INSA includes TOSV-specific real-time reverse transcription polymerase chain reaction (RT-PCR) ${ }^{18}$ followed by conventional RT-PCR and sequencing if the sample resulted positive. ${ }^{19}$ In the first days of viremia the sample of choice for direct 
detection and isolation of TOSV is the cerebrospinal fluid (CSF). However, the data suggests that urine may also be used as a valid clinical sample for detection of TOSV RNA in suspected cases, particularly in individuals whose specimens for viral diagnosis could not be collected during the early stages of infection. ${ }^{20}$

Most of the time, only serum samples are available and indirect diagnosis is the only option. In this case, the samples are tested for the presence of $\operatorname{lgM}$ and $\lg G$ antibodies by immunofluorescence assays (IFA). CEVDI/INSA has two types of IFA available: one is an in-house assay for the detection of antibodies anti-TOSV ${ }^{21}$ and the other is a commercial one (Euroimmun, Lübeck, Germany), which consists in a mosaic of viruses which allows us to detect antibodies against four different phleboviruses: SFNV, TOSV, SFSV and sandfly fever Cyprus virus. Screening for TOSV is performed when diagnosis is required for arboviruses or vector-borne neurotropic viruses, or specifically for TOSV. In this study, diagnostic requests for the last 10 years (20092018) were analyzed.

The diagnostic samples studied at CEVDI/INSA were collected in accordance with ethical regulations from the National Institute of Health, Portugal, in a codified database preserving the confidentiality of personal data, therefore, it was not necessary to request approval by the ethics committee.

\section{RESULTS}

TOSV diagnostics was performed for 608 patients from January 2009 to December 2018. Five recent (acute) TOSV infections were confirmed by lgM and IgG positive samples as well as an acute SFSV infection (Table 1). Three other patients had serological evidence of previous contact with TOSV (IgG antibodies only). Four of the patients with acute infection presented with neurological involvement and the other two, including the child infected with SFSV, presented with febrile syndrome (Table 2).

Three of the acute cases were confirmed in specific TOSV serology requests and the remaining three in arboviruses serology requests. Recent infections were most likely acquired in the districts of Faro (3), Lisbon (2) and Setúbal (1).

Most specific requests for serological diagnosis for TOSV were sent by clinicians from hospitals located at the districts of Faro (77\%), Lisbon (12\%) and Oporto (2\%).

\section{DISCUSSION}

In the scientific literature there is a contrast between the number of acute infections and seroprevalence data of TOSV infections, suggesting that a significant proportion of infections caused by this phlebovirus is asymptomatic, or causes mild symptoms that do not warrant a visit to healthcare facilities. This leads to an underestimation of the number of non-neuroinvasive infections caused by TOSV, ${ }^{22}$ and thereby increased concerns about the risk of virus transmission through blood transfusions and organ transplantation to vulnerable individuals. ${ }^{23}$

The number of laboratory diagnosis requests for TOSV is low in Portugal, when compared to other less prevalent vector-borne viruses circulating in the Mediterranean basin, indicating that this virus is still not sufficiently recognized as an etiological agent by clinicians. In some regions of Spain,

Table 1 - Diagnostic requests for TOSV, 2009-2018

\begin{tabular}{|c|c|c|c|c|c|c|c|c|c|c|c|}
\hline Diagnostic request & $\begin{array}{c}2009 \\
n /+\end{array}$ & $\begin{array}{c}2010 \\
n /+\end{array}$ & $\begin{array}{c}2011 \\
n /+\end{array}$ & $\begin{array}{c}2012 \\
n /+\end{array}$ & $\begin{array}{c}2013 \\
n /+\end{array}$ & $\begin{array}{c}2014 \\
n /+\end{array}$ & $\begin{array}{c}2015 \\
n /+\end{array}$ & $\begin{array}{c}2016 \\
\mathrm{n} /+\end{array}$ & $\begin{array}{c}2017 \\
n /+\end{array}$ & $\begin{array}{c}2018 \\
n /+\end{array}$ & Total \\
\hline TOSV (serology) & $5 / 0$ & $13 / 2$ & $15 / 0$ & $15 / 1$ & $7 / 0$ & $11 / 0$ & $6 / 0$ & $8 / 0$ & $4 / 0$ & $6 / 0$ & $90 / 3$ \\
\hline TOSV (RNA detection) & $0 / 0$ & $0 / 0$ & $0 / 0$ & $0 / 0$ & $4 / 0$ & $2 / 0$ & $10 / 0$ & $8 / 0$ & $6 / 0$ & $10 / 0$ & $40 / 0$ \\
\hline Arbovirus (serology) & $29 / 0$ & $46 / 0$ & $54 / 2$ & $39 / 0$ & $40 / 0$ & $26 / 0$ & $45 / 0$ & $71 / 0$ & $65 / 1^{\#}$ & $58 / 0$ & $473 / 3$ \\
\hline Neurotropic viruses (RNA detection) & $0 / 0$ & $0 / 0$ & $0 / 0$ & $0 / 0$ & $1 / 0$ & $2 / 0$ & $0 / 0$ & $0 / 0$ & $0 / 0$ & $2 / 0$ & $5 / 0$ \\
\hline Total & $36 / 0$ & $59 / 2$ & $69 / 2$ & $54 / 1$ & $52 / 0$ & $41 / 0$ & $61 / 0$ & $87 / 0$ & $75 / 1$ & $76 / 0$ & $608 / 6$ \\
\hline
\end{tabular}

n/+: patients/confirmed cases; \#: infection by SFSV

Table 2 - Clinical manifestations and results of the immunofluorescence assay (IFA) in patients with recent or past infections by TOSV and SFSV

\begin{tabular}{|c|c|c|c|c|c|}
\hline Year & Patient number & Living area and probable place of infection & Clinical manifestations & $\begin{array}{l}\text { IFA } \\
\text { IgM }\end{array}$ & $\begin{array}{l}\text { IFA } \\
\text { IgG }\end{array}$ \\
\hline 2009 & 1 & Portalegre & Und & - & + \\
\hline 2010 & $2^{*}$ & Faro & Meningoencephalitis & + & + \\
\hline 2010 & $3^{*}$ & Faro & Lymphocytic meningitis & + & + \\
\hline 2010 & 4 & Faro & Lymphocytic meningitis & - & + \\
\hline 2011 & $5^{*}$ & Setúbal & Severe depression of consciousness & + & $\mathrm{Nr}$ \\
\hline 2011 & $6^{*}$ & Lisbon & Febrile syndrome and rash & + & + \\
\hline 2012 & $7^{*}$ & Faro & Meningitis & + & $\mathrm{Nr}$ \\
\hline 2014 & 8 & Faro & Und & $\mathrm{Nr}$ & + \\
\hline 2017 & $9^{*}$ & Lisbon & Febrile syndrome, anorexia, asthenia & + & + \\
\hline
\end{tabular}

* recent infection; Und: data not available; Nr: not requested; +: positive; -: negative 
TOSV is considered as the third cause of aseptic meningitis in the summer months. ${ }^{24}$

The fact that the largest number of TOSV-specific diagnostic requests originated in Faro district seems to indicate a higher level of recognition by clinicians in that region. In a retrospective study published in 2011 , cases were reported in the districts of Faro, Coimbra and Aveiro, and seroprevalence was detected in other districts such as Évora and Santarém. ${ }^{25}$ The acute infections described in the present study originated from the districts of Faro, Lisbon and Setúbal. Phlebotomus perniciosus, the recognized vector of TOSV, is the most ubiquitous sandfly species in Portugal, which reinforces the fact that this virus may be distributed throughout the mainland territory.

In Portugal, SFSV was previously described in a human seroprevalence study in $1974,{ }^{26}$ but has now been associated with disease, for the first time in $2017,{ }^{27}$ alerting to the circulation of this phlebovirus in the country. In the last decade new phleboviruses have been associated with human infection and there is molecular and serological evidence of Sicilian virus-related outbreaks in the Mediterranean and Middle East. Detection of anti-SFSV antibodies in studies performed on dogs and cats in Portugal ${ }^{28-30}$ corroborates once again the circulation of this virus in our country.

To date, two new phleboviruses have been isolated whose genome has been fully sequenced in Portugal: Arrabida virus ${ }^{31}$ (SFNV group) and Alcube virus ${ }^{32}$ (SALV group). Massilia virus (SFNV group), isolated for the first time in France, ${ }^{33}$ was also detected in our country and fully sequenced. ${ }^{32}$ Given that TOSV was isolated from its vector in 1971, and only 12 years later proved to be a relevant pathogen, the importance of these phleboviruses in public health should be clarified.

The diagnosis of phleboviruses should be considered in, the warmer months, in cases of neurological disease or febrile syndrome of unknown origin. It is known that treatment often only serves to reduce symptoms; however, as Veater and colleagues have shown (2017), ${ }^{34}$ the usefulness of a correct diagnosis of TOSV is that it can reduce and/or prevent the unnecessary use of antibiotics. Furthermore, both patient and family can be reassured that in general, this illness is self-limiting with full recovery expected within a few weeks.

This work summarizes ten years of TOSV diagnostics in Portugal and its ultimate purpose is to raise awareness about the presence of sandfly-borne phleboviruses in our country. Six acute infections were reported, which demonstrates that this group of viruses is causing disease in mainland Portugal. The increasing number of newly described phleboviruses, especially in the Mediterranean basin, raises concerns. Portugal is no exception, since there are, at least, five phleboviruses in circulation, namely, TOSV, SFSV, Arrabida, Alcube and Massilia and the implications of the latter three in human or veterinary health are unknown.

The number of TOSV diagnostic requests to the CEVDI/
INSA is very low. Furthermore, we believe that some of the few CSF samples arriving to the lab may have not been properly stored. Since phleboviruses are RNA viruses, their genetic material can degrade. This fact makes the detection of these pathogens during the viremic phase (only up to three days) even more difficult. In brief, as in other countries the number of phlebovirus infections in Portugal is clearly underestimated because asymptomatic or mild cases may never end up being diagnosed, some samples are inadequately stored, and finally, there is a generalized lack of awareness, in our country, about the implications of phleboviruses in human health.

\section{CONCLUSION}

Even though the number of identified TOSV cases in Portugal is low, it circulates and causes disease in our country. The diagnosis of this and of other phleboviruses should not be neglected in the differential diagnosis of febrile syndromes, viral meningitis and meningoencephalitis, especially during the warmer months, when their vector's activity is higher.

\section{AUTHORS CONTRIBUTION}

FA: Conception of the work, draft of the paper, performed serologic diagnosis.

LZZ: Draft of the paper, performed molecular and serological diagnosis.

MTL: Performed the techniques for the serological diagnosis, critical review of the paper.

MJA: Draft of the paper, performed serologic diagnosis.

\section{ACKNOWLEDGEMENTS}

The authors would like to thank Natacha Milhano for the revision of the manuscript.

\section{PROTECTION OF HUMANS AND ANIMALS}

The authors declare that the procedures were followed according to the regulations established by the Clinical Research and Ethics Committee and to the Helsinki Declaration of the World Medical Association updated in 2013.

\section{DATA CONFIDENTIALITY}

The authors declare having followed the protocols in use at their working center regarding patients' data publication.

\section{COMPETING INTERESTS}

The authors have declared that no competing interests exist.

\section{FUNDING SOURCES}

This work was partially supported by the FCT Project: Phleboviruses in Portugal: vectors pathogenesis and coinfections (PTDC/DTP-SAP/0859/2014). 


\section{REFERENCES}

1. Papa A, Velo E, Bino S. A novel phlebovirus in Albanian sandflies. Clin Microbiol Infect. 2011;17:585-7.

2. Anagnostou V, Pardalos G, Athanasiou-Metaxa M, Papa A. Novel phlebovirus in febrile child, Greece. Emerg Infect Dis. 2011;17:940-1.

3. Sabin A, Philip C, Paul J. Phlebotomus (pappataci or sandfly) fever: a disease of military importance; summary of existing knowledge and preliminary report of original investigations. JAMA. 1944;125:603-6 and 693-9.

4. Papa A, Konstantinou G, Pavlidou V, Antoniadis A. Sandfly fever virus outbreak in Cyprus. Clin Microbiol Infect. 2006;12:192-4.

5. Bartelloni P, Tesh R. Clinical and serologic responses of volunteers infected with phlebotomus fever virus (Sicilian type). Am J Trop Med Hyg. 1976;25:456-62.

6. Leoncini F, Bartolozzi D, Banchi S. Il virus Toscana: un nuovo Phlebovirus causa di malattie infiammatorie acute del SNC nell'uomo. Giorn Mal Inf Parass. 1986;38:649-52.

7. Ehrnst A, Peters CJ, Niklasson B, Svedmir A, Holmgren B. Neurovirulent Toscana virus (a sand fly fever virus) in Swedish man after visit to Portugal. Lancet 1985;1:1212-3.

8. Pierro A, Ficarelli S, Ayhan N, Morini S, Raumer L, Bartoletti M, et al. Characterization of antibody response in neuroinvasive infection caused by Toscana virus. Clin Microbiol Infect. 2017;23:868-73.

9. Arden KE, Heney C, Shaban B, Nimmo GR, Nissen MD, Sloots TP, et al. Detection of Toscana virus from an adult traveler returning to Australia with encephalitis. J Med Virol. 2017;89:1861-4.

10. Bartels S, de Boni L, Kretzschmar HA, Heckmann JG. Lethal encephalitis caused by the Toscana virus in an elderly patient. J Neurol. 2012;259:175-7.

11. Rota E, Morelli N, Immovilli P, De Mitri P, Guidetti D. Guillain-Barré-like axonal polyneuropathy associated with Toscana virus infection: a case report. Medicine. 2017;96:e8081.

12. Baldelli F, Ciufolini MG, Francisci D, Marchi A, Venturi G, Fiorentini $C$, et al. Unusual presentation of life-threatening Toscana virus meningoencephalitis. Clin Infect Dis. 2004;38:515-20.

13. Oechtering J, Petzold G. Acute hydrocephalus due to impaired CSF resorption in Toscana virus meningoencephalitis. Neurology. 2012;79:829-31.

14. Martínez-García F, Moreno-Docón A, Segovia-Hernández M, Fernández-Barreiro A. Sordera como secuela de meningitis por el virus Toscana. Med Clin. 2008;130:639.

15. Sanbonmatsu-Gámez S, Pérez-Ruiz M, Palop-Borrás B, Navarro-Marí JM. Unusual manifestation of Toscana virus infection, Spain. Emerg Infect Dis. 2009;15:347-8.

16. Mosnier E, Charrel R, Vidal B, Ninove L, Schleinitz N, Harlé JR, et al. Toscana virus myositis and fasciitis. Med Mal Infect. 2013;43:208-10.

17. Tschumi F, Schmutz S, Kufner V, Heider M, Pigny F, Schreiner B, et al. Meningitis and epididymitis caused by Toscana virus infection imported to Switzerland diagnosed by metagenomic sequencing: a case report. BMC Infect Dis. 2019;19:591.

18. Pérez-Ruiz M, Collao X, Navarro-Marí JM, Tenorio A. Reverse transcription, real-time PCR assay for detection of Toscana virus. J Clin Virol. 2007;39:276-81.

19. Sánchez-Seco MP, Echevarría JM, Hernández L, Estévez D, Navarro-
Mari JM, Tenorio A. Detection and identification of Toscana and other phleboviruses by RT-nested-PCR assays with degenerated primers. J Med Virol. 2003;71:140-9.

20. Ergunay K, Kaplan B, Okar S, Akkutay-Yoldar Z, Kurne A, Arsava EM, et al. Urinary detection of toscana virus nucleic acids in neuroinvasive infections. J Clin Virol. 2015;70:89-92.

21. Amaro F, Luz T, Parreira P, Marchi A, Ciufolini M, Alves M. Serological evidence of Toscana virus infection in Portuguese patients. Epidemiol Infect. 2012;140:1147-50.

22. Charrel R, Bichaud L, de Lamballerie X. Emergence of Toscana virus in the mediterranean area. World J Virol. 2012;1:135-41.

23. Brisbarre N, Attoui H, Gallian P, Bonito P, Giorgi C, Cantaloube JF, et al. Seroprevalence of Toscana virus in blood donors, France, 2007. Emerg Infect Dis. 2011;17:941-3.

24. de Ory Manchón F, Gegúndez Cámara MI, Fedele CG, Sánchez-Seco MP. Virus Toscana, West Nile y de la coriomeningitis linfocitaria como causantes de meningitis aséptica en España. Med Clin. 2009;132:58790 .

25. Amaro F, Luz T, Parreira P, Ciufolini MG, Marchi A, Janeiro N, et al. Vírus Toscana na população Portuguesa: vigilância sero-epidemiológica e casos clínicos. Acta Med Port. 2011;24:S503-8.

26. Filipe A. Serological survey for antibodies to arboviruses in the human population of Portugal. Trans R Soc Trop Med Hyg. 1974;68:311-4.

27. Guerra AB, Gouveia C, Zé Zé L, Amaro F, Ferreira GC, Brito MJ. Prolonged febrile illness caused by Sicilian virus infection in Portugal. $36^{\text {th }}$ Annual meeting of the European Society for Paediatric Infectious Diseases. Malmo: ESPID; 2018.

28. Maia C, Alwassouf S, Cristóvão J, Ayhan N, Pereira A, Charrel R, et al. Serological association between Leishmania infantum and sand fly fever Sicilian (but not Toscana) virus in sheltered dogs from southern Portugal. Parasit Vectors. 2017;10:92.

29. Alwassouf S, Maia C, Ayhan N, Coimbra M, Cristovao JM, Richet $\mathrm{H}$, et al. Neutralization-based seroprevalence of Toscana virus and sandfly fever Sicilian virus in dogs and cats from Portugal. J Gen Virol. 2016;97:2816-23.

30. Pereira A, Ayhan N, Cristóvão J, Vilhena H, Martins Â, Cachola P, et al. Antibody response to Toscana virus and sandfly fever Sicilian virus in cats naturally exposed to Phlebotomine sand fly bite in Portugal. Microorganisms. 2019;7:339.

31. Amaro F, Hanke D, Zé-Zé L, Alves MJ, Becker SC, Höper D. Genetic characterization of Arrabida virus, a novel phlebovirus isolated in South Portugal. Virus Res. 2016;214:19-25.

32. Amaro F, Zé-Zé L, Alves MJ, Börstler J, Clos J, Lorenzen S, et al Co-circulation of a novel phlebovirus and Massilia virus in sandflies, Portugal. Virol J. 2015;12:174.

33. Charrel RN, Moureau G, Temmam S, Izri A, Marty P, Parola P, et al Massilia virus, a novel Phlebovirus (Bunyaviridae) isolated from sandflies in the Mediterranean. Vector Borne Zoonotic Dis. 2009;9:51930 .

34. Veater J, Mehedi F, Cheung CK, Nabarro L, Osborne J, Wong N, et al. Toscana virus meningo-encephalitis: an important differential diagnosis for elderly travellers returning from Mediterranean countries. BMC Geriatr. 2017;17:193 